\title{
Endocytotic Uptake, Processing, and Retroendocytosis of Human Biosynthetic Proinsulin by Rat Fibroblasts Transfected with the Human Insulin Receptor Gene
}

\author{
James R. Levy, Axel Ulirich, and Jerrold M. Olefsky \\ Department of Medicine, University of California, San Diego, California 92093; the Veterans Administration Medical Center, \\ San Diego, California 92161; and Genentech Company, South San Francisco, California 94080
}

\begin{abstract}
The cellular itinerary and processing of insulin and proinsulin were studied to elucidate possible mechanisms for the observed in vivo differences in the biologic half-lives of these two hormones. A rat fibroblast cell line transfected with a normal human insulin receptor gene was used. Due to gene amplification, the cells express large numbers of receptors and are ideal for studying a ligand, such as proinsulin, that has a low affinity for the insulin receptor. Competitive binding at $4^{\circ} \mathrm{C}$ showed that the concentration of unlabeled insulin and proinsulin that is needed to displace $50 \%$ of tracer insulin or proinsulin was 0.85-0.95 $\mathrm{nM}$ and 140-150 $\mathrm{nM}$, respectively. Binding to surface receptors and internalization occur at rates that are four to five times faster in cells incubated with insulin compared with proinsulin. Chloroquine led to an increase in cell-associated radioactivity of $\sim 1$.4-fold in cells incubated with insulin or proinsulin, but inhibited the appearance of degraded insulin by $54 \%$ and degraded proinsulin by only $10 \%$. To study the fate of internalized ligand, cells were incubated with insulin and proinsulin until steady state binding occurred. Surface bound ligand was removed by an acid wash and the remaining cell-associated radioactivity represented internalized ligand. Cells were then reincubated in $37^{\circ} \mathrm{C}$ buffer and the cell-associated radioactivity and radioactivity released into the medium were analyzed by TCA precipitation, Sephadex G-50, and HPLC. The results demonstrated that proinsulin more readily bypasses the intracellular degradative machinery and is therefore released intact from the cell via the retroendocytotic pathway. These results may help to explain the prolonged metabolic clearance rate and biologic responsiveness of proinsulin in vivo.
\end{abstract}

\section{Introduction}

With the successful production of large quantities of human proinsulin (HPro) ${ }^{1}$ by means of recombinant DNA techniques $(1,2)$, interest has been growing in the comparison of the

Address all correspondence to Dr. Jerrold M. Olefsky, Department of Medicine, M-023E, University of California, San Diego, La Jolla, CA 92093.

Received for publication 22 May 1987 and in revised form 23 November 1987.

1. Abbreviations used in this paper: HIRC, normal human insulin receptor; HPro, human proinsulin.

J. Clin. Invest.

(c) The American Society for Clinical Investigation, Inc. 0021-9738/88/05/1370/08 \$2.00

Volume 81, May 1988, 1370-1377 kinetics and physiologic effects of proinsulin and insulin. In vivo studies of HPro action have established that the prohormone differs significantly from insulin. Proinsulin's effects, which consist of increasing glucose disposal rate and suppressing hepatic glucose output, develop more slowly than insulin's effects (3-8). Furthermore, the duration of the biological effects in vivo of HPro is markedly prolonged relative to those of insulin, which is only partially explained by the differences in the circulating half-lives of insulin and HPro (6-8). These findings suggest that some process distal to serum HPro levels contribute to the markedly prolonged biologic half-life of this hormone.

In vitro studies to date have not elucidated the possible mechanisms underlying the observed in vivo differences in the kinetics of insulin and proinsulin action. Using isolated rat adipocytes or cultured rat hepatocytes, no differences have been found between insulin and proinsulin in the activation or deactivation of glucose transport (9-11), nor in glucose incorporation into lipid (10). Thus, it is unlikely that a delayed or prolonged "postreceptor" or intracellular action of proinsulin is responsible for the observed in vivo differences between the two hormones. Therefore, it seemed possible that differences in cellular processing of the two hormones might exist. After binding of insulin to the receptor, the hormone enters the cell via receptor-mediated endocytotic uptake. After internalization, most of the insulin is degraded; however, a significant proportion is released intact (12-14). This pathway has been referred to as transcytosis in endothelial cells (14) and retroendocytosis $(12,13)$ in peripheral target tissues, and may be important in preserving the biologic signal for insulin action (12).

Due to the markedly reduced binding affinity of proinsulin, studies of proinsulin cellular processing have proven difficult, and relatively little information exists. Binding and internalization studies conducted in the past have relied on the use of large amounts of target tissue, which presents conditions that lead to significant extracellular hormone degradation and compromise cell viability. Furthermore, results have varied greatly, which may be largely due to the relatively high proportion of nonspecific to specific binding $(9-11,15,16)$. To overcome some of these problems, we have studied insulin and proinsulin binding and processing in rat fibroblasts that have been transfected with the normal human insulin receptor (HIRC) gene. Due to gene amplification these cells express large numbers of receptors $\left(\sim 1.2 \times 10^{6} /\right.$ cell $)$ and, therefore, provide an ideal model to study cellular processing of HPro. In these cells receptors internalize, recycle, and mediate insulin degradation in a normal manner (17). The current studies show that HIRC cells bind and internalize HPro with a slower time course. Additionally, HPro is degraded less efficiently via a chloroquine-sensitive pathway, and a greater proportion of internalized HPro enters the nondegradative, retroendocytotic pathway. 


\section{Methods}

Cell culture. Stable lines of Rat I fibroblasts transfected with a plasmid containing the HIRC gene as well as the gene for dihydrofolate reductase were prepared as previously described $(17,18)$. Cells were grown in T75 flasks (Costar, Data Packaging Corp., Cambridge, MA) in DME with $10 \%$ FCS and $500 \mathrm{nM}$ methotrexate. $2-3 \mathrm{~d}$ before an experiment, 60-mm culture dishes (Costar) were seeded with $0.5-5 \times 10^{5}$ cells/dish with the above media.

Measurements of insulin binding and internalization. The radiolabeled ligands used in these experiments consisted of monoiodinated insulin and proinsulin with the ${ }^{125} \mathrm{I}$ incorporated into the tyrosine that corresponds to position 14 of the insulin A chain for both ligands (15). After washing three times with $2 \mathrm{ml}$ of binding buffer (MEM, $25 \mathrm{mM}$ Hepes, $25 \mathrm{mM}$ tricine, $1 \% \mathrm{BSA}$ ), monoiodinated ${ }^{125} \mathrm{I}-\mathrm{A}^{14}$-insulin (porcine) or monoiodinated human ${ }^{125} \mathrm{I}-\mathrm{A}^{14}$-proinsulin (15), in addition to varying concentrations of cold pork insulin or human proinsulin, were added to a final volume of $2 \mathrm{ml}$ of binding buffer at $\mathrm{pH} 7.6,4-37^{\circ} \mathrm{C}$. Unless otherwise indicated, the concentrations of radiolabeled insulin and proinsulin were 0.1 and $1.0 \mathrm{nM}$, respectively. After the desired incubation period, the cells were washed five times with $2 \mathrm{ml}$ of PBS, pH 7.4 at $4^{\circ} \mathrm{C} .1 \mathrm{ml}$ of $0.1 \mathrm{~N} \mathrm{NaOH}$ was added to each dish, which was then shaken for $30 \mathrm{~min}$ at $37^{\circ} \mathrm{C}$ to solubilize the cells and release them from the dish. After the dishes were washed with an additional $1 \mathrm{ml}$ of $0.1 \mathrm{~N} \mathrm{NaOH}$, the total cell-associated radioactivity was quantitated by counting the solubilized cell solution and the wash in a counter (model 4000; Beckman Instruments, Inc., Fullerton, CA). The specific cell-associated radioactivity was calculated by subtracting the cell-associated radioactivity found in cells that were incubated in the presence of 2 $\mu \mathrm{g} / \mathrm{ml}$ of either cold insulin or proinsulin (nonspecific cell-associated radioactivity) from the total cell-associated radioactivity found at tracer ligand concentrations.

Cell-associated radioactivity represents both ligand bound to the plasma membrane receptor and internalized radioactivity. Internalized cell-associated radioactivity was determined based on the principle that surface receptor-bound ligand can be removed by exposing cells to a low $\mathrm{pH}$ at low temperatures as was first reported by Haigler (19). Using this method, the non-acid-extractable radioactivity represents internalized radioactivity. After the cells were preincubated at $37^{\circ} \mathrm{C}$ for the indicated time periods, they were rapidly cooled to $4^{\circ} \mathrm{C}$ by being washed five times with $2 \mathrm{ml}$ of PBS at $4^{\circ} \mathrm{C}$. All intracellular processing, and release of intracellular radioactivity, is inhibited at this

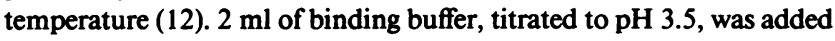
to the dishes and vigorously shaken at $4^{\circ} \mathrm{C}$ for $10 \mathrm{~min}$. The cells were washed three more times with $2 \mathrm{ml}$ of $4^{\circ} \mathrm{C}$, acidic binding buffer, and three times with $2 \mathrm{ml}$ of $\mathrm{PBS}, 4^{\circ} \mathrm{C}$. Control experiments to determine the efficiency of the removal of surface receptor-bound insulin revealed that when cells were incubated with ${ }^{125}$ I-insulin or proinsulin for $90 \mathrm{~min}$ at $4^{\circ} \mathrm{C}$ (a temperature where internalization is completely inhibited), $>99 \%$ of the cell-associated radioactivity was extracted (data not shown).

The protein content of each dish was determined by using the protocol of Lowry et al. (20).

Release of internalized cell-associated material. After cells were incubated for 20 or $120 \mathrm{~min}$ at $37^{\circ} \mathrm{C}$ with monoiodinated insulin and proinsulin, respectively, the cells were cooled, and after acid was extracted as described above, they were washed five times with PBS to remove all extracellular radioactivity. After aspirating the final wash, 2 $\mathrm{ml}$ of $37^{\circ} \mathrm{C}$ binding buffer was added and the cells were reincubated at $37^{\circ} \mathrm{C}$. At the indicated times, $1 \mathrm{ml}$ of buffer was removed and the radioactivity was analyzed either by Sephadex G-50 gel chromatography or by its ability to precipitate in $7.5 \%$ TCA. The cell-associated radioactivity was measured as described above or solubilized in $1 \mathrm{ml}$ of $1 \%$ Triton X-100, $4 \mathrm{M}$ urea, $1 \mathrm{M}$ acetic acid, and applied to a Sephadex G-50 column.

Chromatography. Sephadex G-50 chromatography was performed using a $0.9 \times 50 \mathrm{~cm}$ column previously standardized with ${ }^{125} \mathrm{I}-\mathrm{A}^{14}$-insulin or iodinated human proinsulin. $1 \mathrm{ml}$ of radioactive material was layered onto the column and eluted with $1 \mathrm{M}$ acetic acid, 0.1\% BSA, and $1-\mathrm{ml}$ fractions were collected as previously described (12). Recovery was $>95 \%$ of the total counts applied. Samples prepared for reverse phase HPLC were applied to Sephadex columns and eluted with only $1 \mathrm{M}$ acetic acid. The columns, however, were previously exposed to BSA.

Reverse phase HPLC was performed using a modified protocol of Frank et al. (21). Radioactive samples, dissolved in $0.1 \mathrm{~N} \mathrm{HCl}$, were applied using a 1-ml sample loop to a C-18 analytic column (C-18; Bondapak, Waters Associates, Milford, MA). The column eluant was derived from solvents $\mathrm{A}$ and $\mathrm{B}$ using a 30 -min linear gradient from $25 \%$ acetonitrile to $35 \%$ acetonitrile in $0.3 \mathrm{M}\left(\mathrm{NH}_{4}\right)_{2} \mathrm{SO}_{4}, \mathrm{pH}$ $6.0,22^{\circ} \mathrm{C}$.

\section{Results}

Binding competition studies were performed by incubating the HIRC cells with either ${ }^{125} \mathrm{I}$-proinsulin or ${ }^{125} \mathrm{I}$-insulin and various concentrations of unlabeled HPro or insulin for $18 \mathrm{~h}$ at $4^{\circ} \mathrm{C}$. Fig. 1, $A$ and $B$ demonstrate that unlabeled HPro competes poorly for both labeled ligands. $50 \%$ inhibition of tracer insulin or proinsulin binding occurred at insulin and proinsulin concentrations of $0.85-0.95 \mathrm{nM}$ and 140-150 nM, respectively, which indicates that proinsulin has an apparent binding potency of $<1 \%$ for insulin. These results are consistent with previous reports and demonstrate that the expressed human
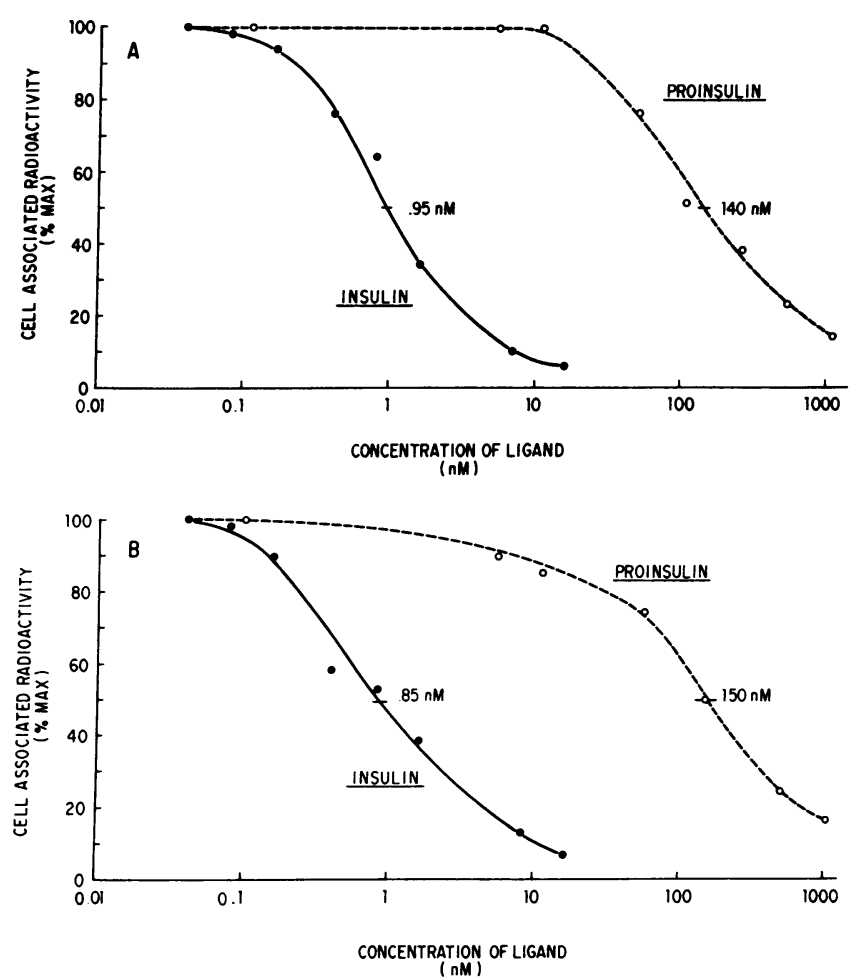

Figure 1. Competitive binding of insulin and HPro to HIRC cells at $4^{\circ} \mathrm{C}$. $(A)$ HIRC cells $\left(4 \times 10^{5} /\right.$ dish) were incubated with ${ }^{125}$ I-insulin $(0.3 \mathrm{ng} / \mathrm{ml})$ and various amounts of either biosynthetic HPro $(\bullet)$ or porcine insulin (O). (B) Same as above except that cells were incubated with ${ }^{125} \mathrm{I}$-proinsulin $(1 \mathrm{ng} / \mathrm{ml})$. Specific binding was determined after $18 \mathrm{~h}$. Each data point represents the mean of triplicate dishes representing two other experiments with similar results. The mean maximal specific binding of labeled tracer ligand for the three experiments was $52.1 \%$ for insulin and $5.7 \%$ for proinsulin. 
insulin receptors behave as do other insulin receptor systems with respect to binding affinity and specificity for insulin and proinsulin.

Insulin target cells internalize the insulin receptor-ligand complex (22). This property was assessed in two ways. Firstly, cells were incubated with tracer concentrations of iodinated ligand at $37^{\circ} \mathrm{C}$ for various times and then exposed to acid to remove surface-bound material. With this approach, nonacid-extractable material was taken as internalized radioactivity and extractable material was considered to be surfacebound, iodinated ligand. The time course of ${ }^{125} \mathrm{I}$-insulin and ${ }^{125} \mathrm{I}$-proinsulin binding and internalization in HIRC cells is seen in Fig. 2. Insulin binding to the cell surface, as reflected by extractable radioactivity, is rapid, reaching a plateau of $\sim 9 \%$ by $10 \mathrm{~min}$. Internalization of insulin, indicated by nonextractable radioactivity, lags behind the rate of surface binding and begins to plateau by $20 \mathrm{~min}$. At steady state, $55 \%$ of the total cell-associated radioactivity is nonextractable, which suggests that $45 \%$ of the insulin is bound to surface receptors and $55 \%$ is internalized. The time courses of proinsulin binding to surface receptors and internalization are much different. Binding and internalization do not reach steady state until $\sim 60$ and 120 min, respectively. The $t_{1 / 2}$ of ligand binding to surface receptors for insulin and proinsulin is 6 and $24 \mathrm{~min}$, respectively, and the $t_{1 / 2}$ for internalization is 8 and $40 \mathrm{~min}$, respectively.

Another way to examine internalization of ligand is to measure the effect of chloroquine on cell-associated radioactivity. Chloroquine, a lysosomotropic agent, has been shown to inhibit intracellular degradation of insulin, leading to accumulation of insulin within the cell (23). As seen in Fig. 3, A and $B$, incubating HIRC cells with $100 \mu \mathrm{M}$ chloroquine results in a similar $140 \%$ increase in cell-associated radioactivity in cells that were incubated with insulin and proinsulin at 20 and $120 \mathrm{~min}$, respectively. Cell-associated radioactivity does not plateau in the presence of chloroquine in the time periods measured. The effect of chloroquine on ligand degradation by HIRC cells was assessed by measuring the rate of appearance in the media of extracellular radioactivity that was soluble in 7.5\% TCA. The inhibitory effect of chloroquine on ligand degradation was more pronounced in cells incubated with insulin than with proinsulin. As seen in Fig. $3 C$, the rate of degrada- tion in cells incubated with insulin was linear in control cells and measured $0.26 \% / \mathrm{min}$ per $100 \mu \mathrm{g}$ protein. Chloroquine decreased the rate to $0.12 \% / \mathrm{min}$ per $100 \mu$ g protein; i.e., chloroquine inhibited the rate of degradation of insulin by $54 \%$. In contrast, the rate of degradation of proinsulin was linear after $60 \mathrm{~min}$ and was only $1 \%$ as fast as insulin $(0.0025 \% / \mathrm{min}$ per $100 \mu \mathrm{g}$ protein); chloroquine inhibited HPro degradation by only $10 \%$.

It has been previously demonstrated that insulin target tissues not only internalize and degrade insulin but also that a significant portion of the internalized ligand is sorted into a nondegradative, retroendocytotic pathway and is released intact from the cell $(12,13)$. To assess the intracellular sorting and processing of insulin and proinsulin in HIRC cells, we incubated the cells with tracer concentrations of ligand until steady state binding and internalization had occurred (20 and $120 \mathrm{~min}$ for insulin and proinsulin, respectively). After the cells were cooled to $4^{\circ} \mathrm{C}$ with ice-cold PBS, they were exposed to $4^{\circ} \mathrm{C}, \mathrm{pH} 3.5$, to remove ligand bound to surface receptors (22). The cells, containing only internalized radioactivity, were reincubated in fresh $37^{\circ} \mathrm{C}$ buffer. The release of internalized cell-associated radioactivity in cells that were preincubated with insulin or proinsulin is shown in Fig. $4 \mathrm{~A}$. Radioactivity in cells that were preincubated with insulin declined more than in those that were preincubated with proinsulin; $50 \%$ of the cellassociated radioactivity was released in 7 vs. $10 \mathrm{~min}$, respectively $(P<0.05)$. By $30 \mathrm{~min}, 92 \%$ of the radioactivity had been released from cells preincubated with insulin compared with $80 \%$ in cells preincubated with proinsulin.

The appearance of internalized radioactivity in the media and its ability to precipitate in $7.5 \%$ TCA is shown in Fig. 4, B and $C$. Of the radioactivity released from the cells at 10,20, and $30 \mathrm{~min}, 35,40$, and $43 \%$ is intact for insulin vs. 43 ( $P$ $<0.05), 55(P<0.05)$, and 55\% $(P<0.05)$ for proinsulin. The rate of appearance of TCA soluble material is much slower in HIRC cells preincubated with proinsulin than those preincubated with insulin, as shown in Fig. $4 C$. In cells preincubated with insulin compared with proinsulin $38 \pm 2 \%$ vs. $21 \pm 4 \%$, $48 \pm 3 \%$ vs. $36 \pm 2 \%$, and $55 \pm 1 \%$ vs. $43 \pm 2 \%(P<0.05)$ of the released radioactivity appears as TCA soluble material at 10 , 20, and $30 \mathrm{~min}$, respectively. Comparable results were ob-
INSULIN

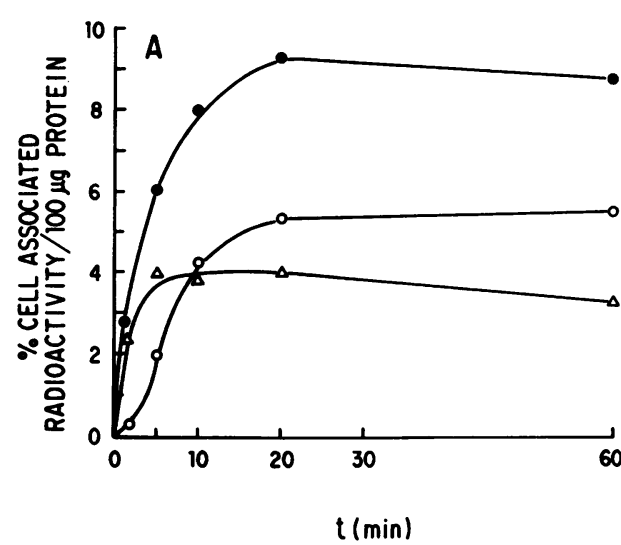

PROINSULIN

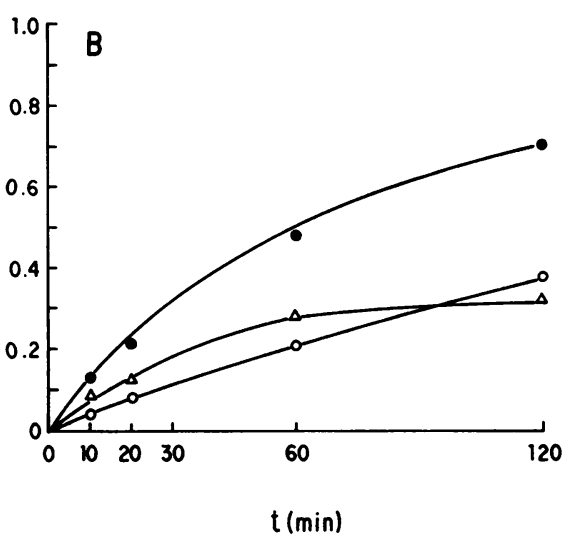

Figure 2. Time courses of binding and internalization. $(A)$ Total specific cellassociated radioactivity $(\bullet)$ was measured at $37^{\circ} \mathrm{C}$ as described in Methods. Tracer ${ }^{125}$ I-insulin concentration was $0.1 \mathrm{nM}$. At the above times, the cells $(70 \mu \mathrm{g} / \mathrm{dish})$ were washed with ice-cold PBS and binding buffer, titrated to $\mathrm{pH}$ 3.5 , was added at $4^{\circ} \mathrm{C}$ to extract surface receptor-bound insulin. The time courses of acid-extractable radioactivity, or surface-bound insulin $(\Delta)$, and nonextractable, cell-associated radioactivity (O), which represents internalized radioactivity, were calculated. $(B)$ Same as above except HIRC cells ( $500 \mu \mathrm{g} /$ dish) were incubated with ${ }^{125} \mathrm{I}$-proinsulin (1 $\mathrm{nM})$. Each data point represents the mean of triplicate dishes from two separate experiments. 

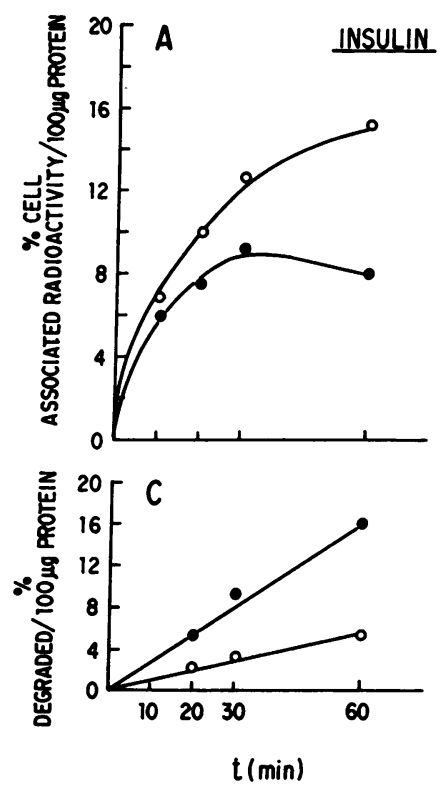

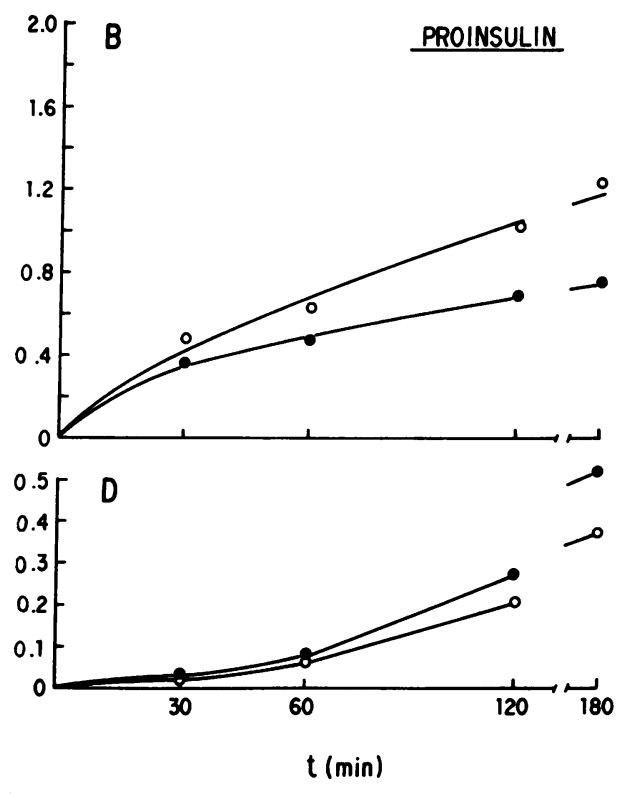

Figure 3. Time course of binding and degradation in the presence and absence of chloroquine. $(A)$ Total specific cell-associated radioactivity was calculated as described in Methods with ${ }^{125} \mathrm{I}$-insulin $(0.1 \mathrm{nM})$ in the presence (0) and absence ( $(0)$ of $100 \mu \mathrm{M}$ chloroquine. $(B)$ Identical to above except the HIRC cells were incubated with ${ }^{125} \mathrm{I}$-proinsulin (1 $\mathrm{nM})$. (C) In experiments performed identically to $A$, insulin degradation in the presence (o) and absence (๑) of $100 \mu \mathrm{M}$ chloroquine was assessed by removing an aliquot of medium at the above times and analyzing the ability of the radioactivity in the medium to remain soluble in $7.5 \%$ TCA. (D) Proinsulin degradation was assessed as in $C$. Each data point represents the mean of triplicate dishes from two separate experiments. served over a range of tracer insulin (0.02-0.1 $\mathrm{nM})$ and proinsulin (0.1-1 nM) concentrations, i.e., the proportion of internalized ligand that is degraded or released intact is constant for both hormones and the differences observed in the processing of insulin and proinsulin are the same at all tracer ligand concentrations tested (data not shown).

The composition of the intracellular and released radioactivity was assessed using Sephadex G-50 gel chromatography. After incubating the cells with tracer concentrations of insulin or proinsulin for 20 or $120 \mathrm{~min}$, the cells were cooled and washed, and the surface-bound ligand was extracted with acid medium. At the indicated times after reincubating the cells in $37^{\circ} \mathrm{C}$, insulin-free buffer, medium was removed and the cells were solubilized. The medium or solubilized cell solution was then placed on Sephadex G-50 columns. The time course for cell-associated radioactivity in cells preincubated with insulin is shown in Fig. $5 A$. Two prominent peaks are demonstrated. The first peak coelutes with intact ${ }^{125} \mathrm{I}$-insulin at fraction 29 and the second peak coelutes with small molecular weight degradation products at fraction 50 . Initially, the intracellular radioactivity is composed of $\sim 80 \%$ material that coelutes with intact insulin and $20 \%$ degradation products. 10 min after the fresh medium was added, the cell-associated material declines rapidly due almost entirely to the fall in the intact insulin peak. By $20 \mathrm{~min}$, intact insulin as well as degraded products decline further and constitute 70 and $30 \%$ of the total cell-associated radioactivity, respectively. The time course of proinsulin-derived, cell-associated radioactivity is shown in Fig. $5 B$. Two peaks are again demonstrated. Intact proinsulin elutes in fraction 24 which is consistent with its molecular weight being greater than insulin's. In contrast to insulin, the percent of the intracellular material that is composed of low molecular weight degradation products is very small, and with time, doesn't change appreciably. As with insulin, however, intact material rapidly declines with time.

With both ligands, the decline of the intact peak could be
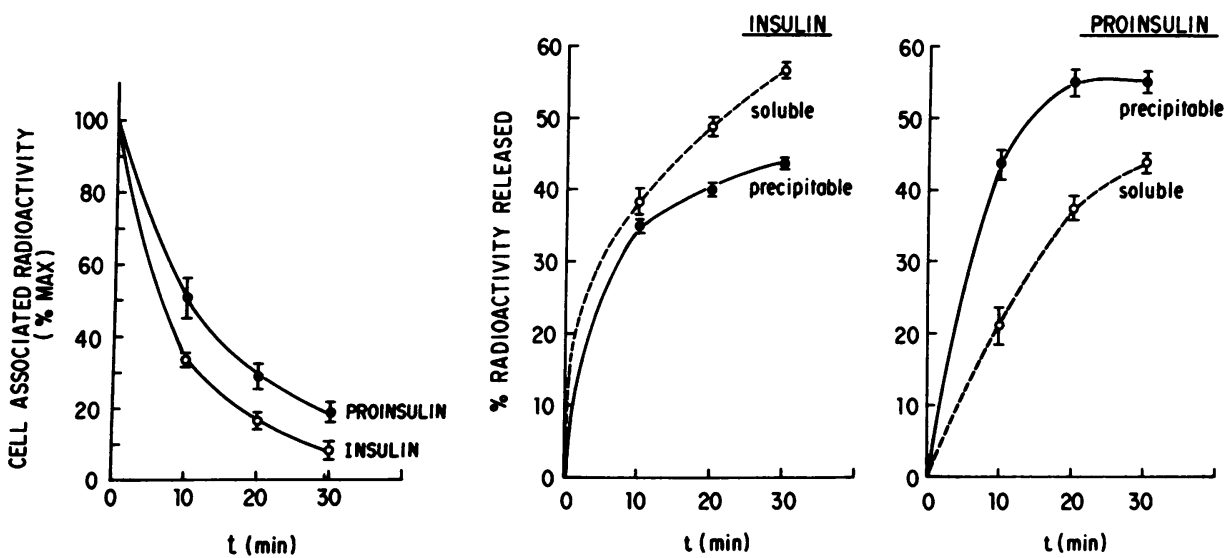

Figure 4. (Left) Time course of release of internalized cell-associated radioactivity from HIRC cells. HIRC cells were incubated with $0.1 \mathrm{nM}^{125}$ I-insulin (o) for $20 \mathrm{~min}$ or $1 \mathrm{nM}{ }^{125} \mathrm{I}$-proinsulin (•) for $120 \mathrm{~min}$ at $37^{\circ} \mathrm{C}$ and surfacebound ligand was removed with a $4^{\circ} \mathrm{C}$ acidic (pH 3.5) buffer. After washing with ice-cold PBS, insulin-free binding buffer was added and at the indicated times, cell-associated radioactivity was measured as described in Methods. (Middle) Time course of appearance of TCA-precipitable (๑) and -soluble (0) material from the internal compartment of HIRC cells incubated with insulin. The experiments were performed at $37^{\circ} \mathrm{C}$ and were identical to the protocol described in $A$ above. The radioactivity in the medium was analyzed for its ability to precipitate in 7.5\% TCA at the given times after fresh insulin-free medium was added. The data were normalized by dividing the radioactivity that was precipitable or soluble at a given time by the total radioactivity released in $30 \mathrm{~min}$. (Right) Time course of appearance of TCA-precipitable (•) and -soluble ( $(0)$ material from cells incubated with proinsulin. The experiments were performed as described above and represent the mean $\pm S E$ of four separate experiments. 


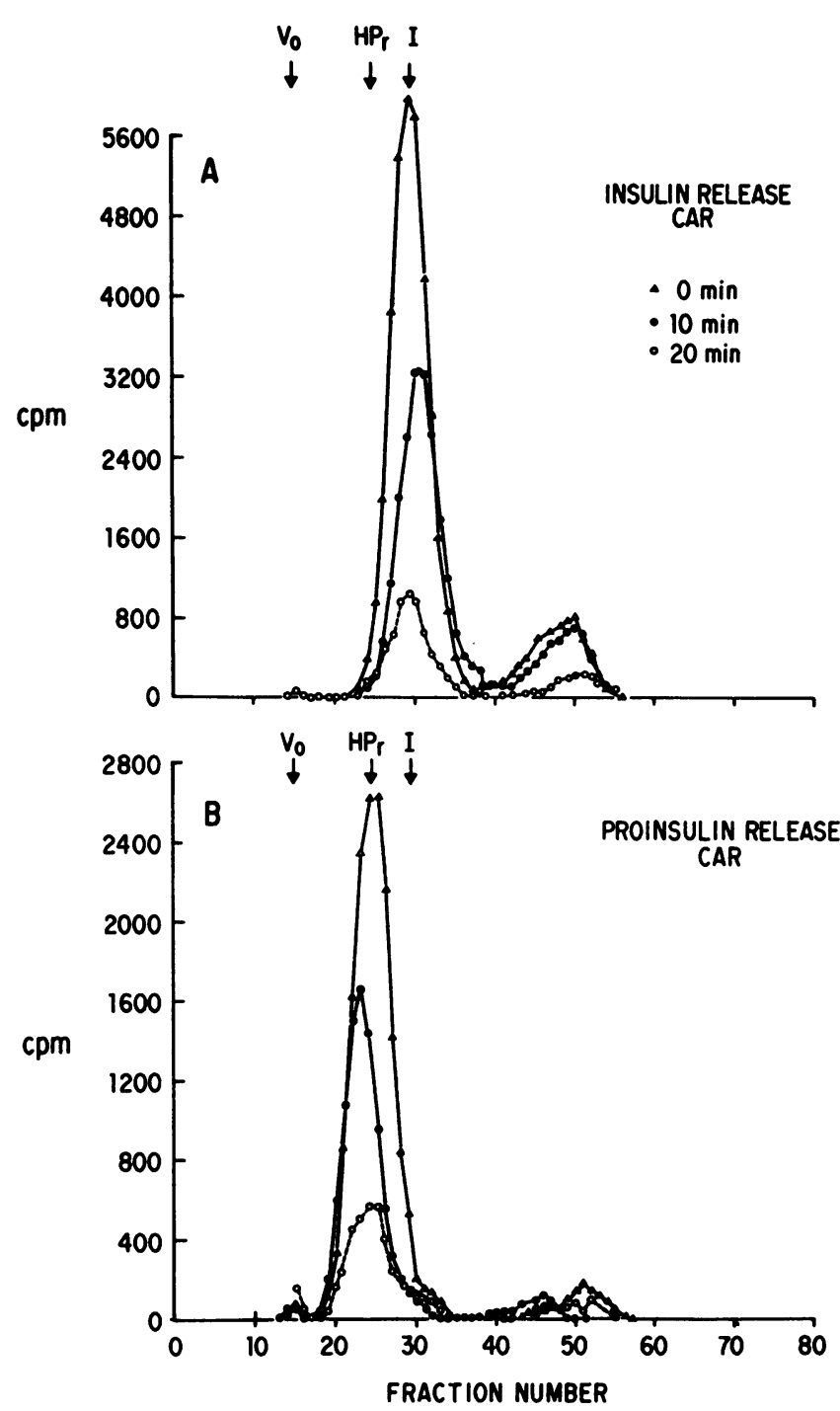

Figure 5. Sephadex G-50 chromatography profiles of the dissociation of intracellular radioactivity. HIRC cells were incubated with either $0.1 \mathrm{nM}^{125}$ I-insulin for $20 \mathrm{~min}(A)$ or $1 \mathrm{nM}^{125} \mathrm{I}$-proinsulin for 120 $\min (B)$, then acid extracted to remove surface receptor-bound insulin, washed, and reincubated with fresh insulin-free buffer. At the indicated times after reincubation, the cells were solubilized as described in Methods and applied to Sephadex G-50 columns.

due theoretically to the release of intact ligand from the cell or to the conversion of intact ligand into low molecular weight degradation products which are subsequently released from the cell. To determine the composition of the released radioactivity, the medium was analyzed by Sephadex G-50 gel chromatography over time. As shown in Fig. $6 A$, both degradation products as well as intact insulin are released in the first $\mathbf{1 0}$ min. However, after $10 \mathrm{~min}$, no additional intact insulin is released while degradation products continue to appear in the medium. Integrating Figs. 5 and $6 A$, the initial fall in intact insulin is due to both the release of intact material from the cell as well as to its conversion into degraded products with subsequent release. However, after $10 \mathrm{~min}$, the fall in intracellular intact insulin is due entirely to the conversion of insulin into low molecular weight degradation products and their release.

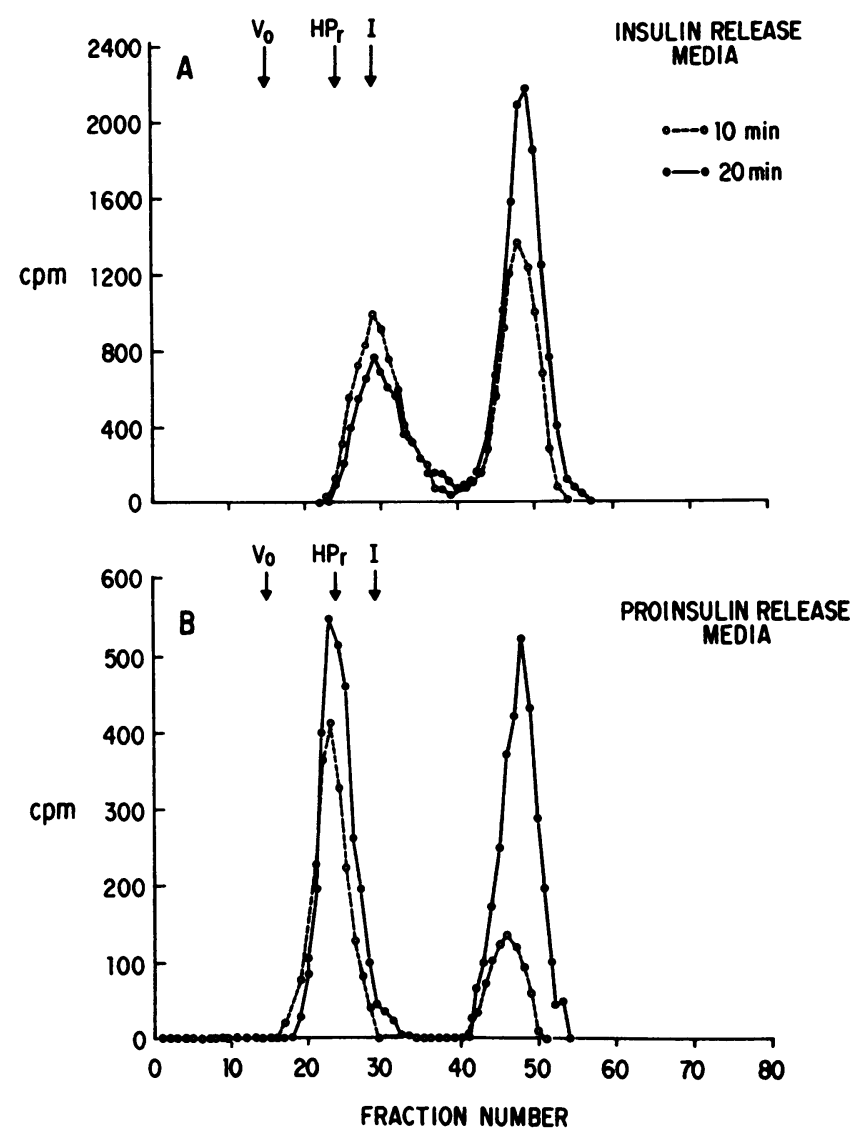

Figure 6. Sephadex G-50 chromatography profiles of the appearance of radioactivity into the medium. The same experiment described in the legend from Fig. 5 was performed here except that instead of measuring cell-associated radioactivity, the medium was placed on a Sephadex column at the indicated times after reincubation in fresh buffer.

The appearance of proinsulin-derived radioactivity is shown in Fig. 6 B. In contrast to insulin, a much higher percentage of proinsulin is released intact both 10 and $20 \mathrm{~min}$ after the addition of fresh $37^{\circ} \mathrm{C}$ media. Intact proinsulin constitutes $72 \%$ of the released radioactivity at $10 \mathrm{~min}$ and $51 \%$ at 20 min compared with values of 47 and $35 \%$ for insulin. In contrast to insulin, a small amount of intact proinsulin is released between 10 and $20 \mathrm{~min}$. However, most of the radioactivity released into the medium from 10 to $20 \mathrm{~min}$ is composed of low molecular weight degradation products. Integrating Figs. 5 and $6 B$, the decline of cell-associated, intact proinsulin in the first $10 \mathrm{~min}$ is mostly due to the release of intact proinsulin. However, between 10 and $20 \mathrm{~min}$, the decline of intact proinsulin is due to the release of proinsulin from the cell as well as to the conversion of proinsulin into degradation products that subsequently appear in the media.

In cells incubated with proinsulin, a peak on Sephadex G-50 that coelutes with intact proinsulin was demonstrated intracellularly as well as in the medium. However, it has been previously shown in various insulin target tissues that material pooled from the intact peak on Sephadex G-50 is actually composed of both intact ligand as well as of intermediates, which can be separated on reverse phase HPLC (24-26). To determine if the intracellular and medium proinsulin was in- 
deed intact, we pooled the fractions in the intact peak from Figs. $5 B$ and $6 B$, lysophilized them, reconstituted them in 0.1 $\mathrm{N} \mathrm{HCl}$, and analyzed them by reverse phase HPLC. The HPLC profiles from the intracellular and medium "intact" proinsulin peaks are shown in Figs. 7, $A$ and $B$. Clearly, both pools eluted with intact proinsulin and no intermediates could be demonstrated.

\section{Discussion}

The cellular itineraries of insulin and HPro were studied to elucidate possible differences in intracellular processing of these two hormones. The studies were performed on rat fibroblasts (which were transfected with cDNA that encodes the HIRC gene) that express $\sim 500$ times the normal number of insulin receptors per cell. Despite proinsulin's low affinity for the insulin receptor, these high expression cells allowed us to perform experiments with a minimal number of cells which resulted in low percentages of nonspecific binding and no extracellular hormonal degradation. Insulin receptors of HIRC cells display similar structure and binding characteristics to receptors of other insulin target tissues. Furthermore, the insulin receptors in HIRC cells internalize, recycle, and mediate insulin degradation in a normal manner (27). Therefore, in view of the high level of insulin receptor expression achieved in these cells, they represent an ideal model with which to study cellular processing of a low affinity insulin agonist such as proinsulin.

The first step in ligand processing is binding of ligand to the receptor. Comparisons of binding potency between HPro and insulin have varied greatly, depending on the target tissue studied. Values for the relative affinity of HPro compared with insulin have ranged from $<1$ to $20 \%(9-11,15,16)$. Although some differences can be attributed to tissue variation as well as to the purity of the proinsulin preparation $(10,11)$, the values can vary greatly because of methodological problems when using radioligands with low affinities and high percentages of nonspecific binding. In HIRC cells, the nonspecific binding was $<2 \%$ of the total HPro binding. The concentration of insulin and proinsulin needed to inhibit tracer insulin or
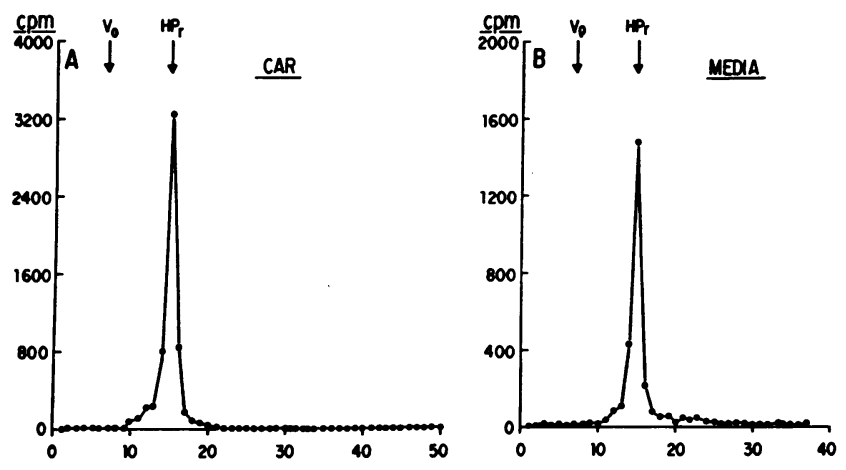

FRACTION NUMBER

Figure 7. HPLC analysis of proinsulin-sized radioactivity, intracellularly $(A)$ and in the medium $(B)$. Sephadex G-50 column fractions containing intracellular (Fig. $5 \mathrm{~B}, 0 \mathrm{~min}$ ) and medium (Fig. $6 \mathrm{~B}, 20$ $\mathrm{min}$ ) proinsulin-sized radioactivity were pooled, lyophilized, and dissolved in $1 \mathrm{ml} 0.1 \mathrm{~N} \mathrm{HCl}$. The sample was applied to a $\mathrm{C}-18$ reverse phase column as described in Methods. proinsulin binding by $50 \%$ was 0.90 and $140 \mathrm{nM}$, respectively, which is similar in magnitude to the binding results seen in isolated rat adipocytes (10). These results show that both hormones bind to the same receptors but with a $>100$-fold difference in affinity.

The lower binding affinity of HPro was reflected in lower rates of tracer hormone binding to surface receptors as well as in reduced rates of more distal cellular processing steps such as internalization and degradation. The $t_{1 / 2}$ values for HPro binding to surface receptors and for subsequent internalization were both four to five times greater than the corresponding $t_{1 / 2}$ values obtained with insulin for the same processes which suggests that the rate of internalization per occupied receptor is similar for either hormone. After internalization, the ligand can be sorted into a degradative pathway and HPro was degraded at a rate only $1 \%$ that of insulin. This relatively slow rate of degradation can also be largely explained by the binding affinity differences of the two ligands leading to proportionately slower rates of processes distal to the binding event. This supports the view that binding to receptors is the initial step in cell-mediated insulin or proinsulin degradation. However, there is an important qualitative difference in the cellular degradation of HPro and insulin. Whereas the majority of degradation of insulin can be inhibited by chloroquine, only a minor proportion of HPro degradation is inhibited by this lysosomotropic agent. This suggests that there are two independent mechanisms for degradation of ligand, one is chloroquine sensitive and mediates most of the insulin degradation, and the other is chloroquine insensitive and mediates most of the HPro degradation. The effect of chloroquine to inhibit insulin degradation is not entirely understood. Chloroquine may have multiple effects on cellular processing such as inhibition of lysosomal function $(28)$, inhibition $(29,30)$ or enhancement (31) of vesicle fusion, and inhibition of trafficking of vesicles (32). In the present study, the fact that chloroquine increased cell-associated radioactivity (see Fig. $3 \mathrm{~B}$ ) in HProtreated cells but only marginally inhibited HPro degradation (see Fig. $3 \mathrm{D}$ ) suggests that chloroquine's effect of increasing cell-associated radioactivity is not due to decreased lysosomal hormone degradation, but to inhibition of processing proximal to lysosomes.

The quantitative differences in insulin and HPro degradation were not simply due to differences in receptor binding. Thus, although the proportions of internalized insulin- or HPro-derived radioactivity was similar at steady state, the amount of intracellular low molecular weight degradation products was much lower in cells incubated with proinsulin compared with those incubated with insulin (see Fig. 5, $A$ and $B, 0 \mathrm{~min}$ ). In other words, in cells incubated with labeled insulin or proinsulin, the steady state intracellular pool is composed of a larger percentage of intact HPro compared with insulin. Part of this intracellular pool of intact ligand is committed to subsequent degradation since the decrease in intracellular intact ligand from 10 to $20 \mathrm{~min}$ is due to conversion to degraded products that are released from the cell. However, a large proportion of this intracellular pool of intact ligand will be released undegraded via the retroendocytotic pathway (12). HPro not only bypasses degradation, but it traverses the retroendocytotic pathway to a much greater extent than insulin. Thus, a larger proportion of internalized HPro is released from the cell intact compared with insulin.

The present study of in vitro cellular processing may ex- 
plain some of the in vivo differences in the kinetics of insulin and HPro biologic action. Binding of hormone to the insulin receptor initiates signals responsible for biologic actions. One component of the mechanisms underlying deactivation of the biologic response is degradation of the ligand (32-35). One may speculate that processes that bypass hormone degradation will most likely tend to preserve or maintain biologic effects, and cells process HPro in ways that can potentially preserve biologic responsiveness. After internalization, a larger fraction of HPro is sorted away from the degradative pathway and into the nondegradative retroendocytotic pathway. Therefore, relative to insulin, HPro can potentially remain associated with the receptor for a longer time and more of it can be released intact from the cell back into the interstitial space. Theoretically, this would maintain a relatively higher and more prolonged hormone concentration at the tissue site of hormone action, which would enable HPro to bind once again to surface receptors and reinitiate a response. Thus, cellular processes such as sorting and retroendocytosis may preserve the actions of HPro and prolong its in vivo biologic half-life.

The precise biochemical mechanisms underlying the reduced rates of degradation and enhanced retroendocytosis of proinsulin compared with those of insulin are not elucidated by the current study. Conceivably, there is a specific sorting signal(s) that targets internalized insulin receptor-bound ligand toward degradative or retroendocytotic pathways. In this event, these intracellular targeting processes might perceive a proinsulin-occupied, internalized receptor differently from a receptor occupied with insulin, leading to differential sorting. Alternatively, there could be ligand-specific differences in the association rates, dissociation rates, and/or the $\mathrm{pH}$ and ionic dependency of these binding processes once the ligand receptor complex is internalized. If such differences led to more prolonged, or stable, proinsulin receptor occupancy, compared with that of insulin, then this might protect proinsulin from the normal intracellular degradative processes and allow more of the proinsulin to remain receptor-bound as the receptor recycles back to the plasma membrane, and this would lead to enhanced retroendocytosis. Although we favor the latter possibility, clearly further studies will be necessary before exact biochemical mechanisms can be determined.

\section{Acknowledgments}

We would like to thank Cleon Tate and Elizabeth Martinez for preparing this manuscript.

This work was supported by National Institutes of Health grants AM-33650 and AM-33651 and the Veterans Administration Medical Research Service, San Diego, CA, and a fellowship grant from the Southern California American Diabetes Association.

\section{References}

1. Ross, M. J. 1980. Production of medically important polypeptides using recombinant DNA technology. Recombinant DNA Technical Bulletin. National Institutes of Health Publication 85-99. 3:1-11.

2. Frank, B. H., J. M. Pettee, R. E. Zimmerman, and P. J. Burck. 1981. The production of human proinsulin and its transformation to human insulin and C-peptide. In Peptides, Structure and Biological Function. D. H. Rich and E. Gross, editors. Pierce Chemical Co., Rockford, IL. 729-738.

3. Sonksen, P. H., C. V. Tompkins, M. C. Srivastava, and J. D. N.
Nabarro. 1973. A comparative study on the metabolism of human insulin and porcine proinsulin in man. Clin. Sci. (Lond.). 45:633-654.

4. Gliemann, J., and H. H. Sorensen. 1972. Assay of insulin-like activity by the isolated fat cell method. IV. The biological activity of proinsulin. Diabetologia. 6:499-504.

5. Tompkins, C. V., D. Brandenburg, R. H. Jones, and P. H. Sonksen. 1981. Mechanism of action of insulin and insulin analogues: a comparison of the hepatic and peripheral effects on glucose turnover of insulin, proinsulin, and three insulin analogues modified at positions A1 and B29. Diabetologia. 20:94-101.

6. Revers, R. R., R. Henry, L. Schmeiser, O. Kolterman, R. Cohen, A. Rubenstein, B. Frank, J. Galloway, and J. M. Olefsky. 1984. Biosynthetic human insulin and proinsulin have additive but not synergistic effects on total body glucose disposal. J. Clin. Endocrinol. \& Metab. 58:1094-1098.

7. Revers, R. R., R. Henry, L. Schmeiser, O. Kolterman, R. Cohen, R. Bergenstal, K. Polonsky, J. Jaspan, R. Rubenstein, B. Frank, J. Galloway, and J. M. Olefsky. 1984. The effects of biosynthetic human proinsulin and carbohydrate metabolism. Diabetes. 33:762-770.

8. Glauber, H. S., R. R. Revers, R. Henry, L. Schmeiser, P. Wallace, O. G. Kolterman, R. M. Cohen, A. H. Rubenstein, J. A. Galloway, B. H. Frank, and J. M. Olefsky. 1986. In vivo deactivation of proinsulin action on glucose disposal and hepatic glucose production in normal man. Diabetes. 35:311-317.

9. Probst, I., H. Hartmann, K. Junguman, and W. Creutzfeldt. 1985. Insulin-like action of proinsulin on rat liver carbohydrate metabolism in vitro. Diabetes. 34:415-419.

10. Peavy, D. E., J. D. Abram, B. H. Frank, and W. C. Duckworth. 1984. In vitro activity of biosynthetic human proinsulin: receptor binding and biologic potency of proinsulin and insulin in isolated rat adipocytes. Diabetes. 33:1062-1067.

11. Ciaraldi, T. P., D. Brady, and J. M. Olefsky. 1986. Kinetics of biosynthetic human proinsulin action in isolated rat adipocytes. Diabetes. 35:318-323.

12. Levy, J. R., and J. M. Olefsky. 1986. Retroendocytosis of insulin in rat adipocytes. Endocrinology. 119:572-579.

13. Marshall, S. 1985. Dual pathways for the intracellular processing of insulin. J. Biol. Chem. 260:13524-13529.

14. King, G. L., and S. M. Johnson. 1985. Receptor-mediated transport of insulin across epithelial cells. Science (Wash DC). 227:1583-1585.

15. Podlecki, D. A., B. H. Frank, and J. M. Olefsky. 1984. In vitro characterization of biosynthetic human proinsulin. Diabetes. 33:111118.

16. Prager, R., and G. Schernthaner. 1982. Receptor binding properties of human insulin (recombinant DNA) and human proinsulin and their interaction at the receptor site. Diabetes Care. 5:104-106.

17. McClain, D. A., H. Maegawa, J. Lee, T. J. Dull, A. Ullrich, and J. M. Olefsky. 1987. A mutant insulin receptor with defective tyrosine kinase displays no biologic activity and does not undergo endocytosis. J. Biol. Chem. 262:14663-14671.

18. Riedel, H., J. Schlessinger, and A. Ullrich. 1987. A chimeric, ligand-binding v-erbB/EGF receptor retains transforming potential. Science (Wash DC). 236:197-200.

19. Haigler, H. T., F. R. Maxfield, M. C. Willingham, and I. Pastan. 1980. Dansyl cadaverine inhibits internalization of ${ }^{125}$ I-epidermal growth factor in BALB 3T3 cells. J. Biol. Chem. 255:1239-1245.

20. Lowry, O. H., N. J. Rosebrough, A. L. Farr, and R. J. Randall. 1951. Protein measurement with the folin phenol reagent. J. Biol. Chem. 193:265-270.

21. Frank, B. H., A. H. Pekar, J. M. Peltee, E. M. Schirmer, M. G. Johnson, and R. E. Chance. 1984. Isolation and characterization of a genetic variant of bovine proinsulin. Int. J. Pept. Protein Res. 23:506515.

22. Olefsky, J. M., and M. Kao. 1978. Surface binding and rates of internalization of ${ }^{125}$ I-insulin in adipocytes and IM-9 lymphocytes. $J$. Biol. Chem. 257:8667-8673.

23. Marshall, S., and J. M. Olefsky. 1979. Effects of lysosomotropic 
agents on insulin interactions with adipocytes: evidence for a lysosomal pathway for insulin processing and degradation. J. Biol. Chem. 254:10153-10160.

24. Peavy, D. E., F. G. Hamel, V. L. Kincke, and W. C. Duckworth. 1985. Evidence that bacitracin alters intracellular insulin metabolism in isolated rat hepatocyte. Diabetes. 34:217-223.

25. Kitabchi, A. E., and F. B. Stentz. 1985. The effect of inhibitors of insulin processing on generation of insulin intermediate products from human fibroblast as detected by high performance liquid chromatography (HPLC). Biochem. Biophys. Res. Commun. 128:163-168.

26. Peavy, D. E., M. R. Brunner, W. C. Duckworth, C. S. Hooker, and B. H. Frank. 1985. Receptor binding and biological potency of several split forms (conversion intermediates) of human proinsulin. $J$. Biol. Chem. 260:13989-13994.

27. McClain, D. A., H. Maegawa, J. Lee, T. J. Dull, A. Ullrich, and J. M. Olefsky. 1987. A mutant insulin receptor with defective tyrosine kinase displays no biologic activity and does not undergo endocytosis. J. Biol. Chem. 262:14663-14671.

28. Varandi, P. T., R. M. Darrow, and M. A. Nofz. 1982. Cellular processing of insulin. Effects of lectin, lysosomotropic and other agents. Am. J. Physiol. 243:E140-144.
29. Posner, B. I., B. A. Patel, M. N. Kahn, and J. Bergeron. 1982. Effect of chloroquine on the internalization of ${ }^{125}$ I-insulin into subcellular fractions of rat liver. J. Biol. Chem. 257:5789-5795.

30. Tollesbaug, H., and T. Berg. 1979. Chloroquine reduces the number of asialoglycoproteins receptors in the hepatocyte plasma membrane. Biochem, Pharmacol. 28:2919-2925.

31. Hart, P. D., and M. R. Young. 1975. The effects of inhibitors and enhancers of phagosomes-lysosome fusion in cultured macrophages on the phagosome membranes of ingested yeasts. Exp. Cell Res. 118:365-370.

32. Terris, S., and D. F. Steiner. 1975. Binding and degradation of ${ }^{125}$ I-insulin by rat hepatocytes. J. Biol. Chem. 250:8389-8395.

33. Duckworth, W. C., and A. E. Kitabchi. 1981. Insulin metabolism and degradation. Endocr. Rev. 2:210-233.

34. Goldstein, B. J., and J. N. Livingston. 1981. Insulin degradation by insulin target cells. Metab. Clin. Exp. 30:825-835.

35. Terris, S., and D. F. Steiner. 1976. Retention and degradation of ${ }^{125} \mathrm{I}$-insulin by perfused livers from diabetic rats. J. Clin. Invest. 58:885-891. 